\title{
Leachability, metal corrosion, and termite resistance of wood treated with copper-based preservative
}

\author{
Lang-Dong Lin ${ }^{\mathrm{a}}$, Yi-Fu Chen ${ }^{\mathrm{b}}$, Song-Yung Wang ${ }^{\mathrm{b}}$, Ming-Jer Tsai ${ }^{\mathrm{b}, *}$ \\ ${ }^{a}$ Department of Forest Products Science, National Chiayi University, Chiayi, Taiwan \\ ${ }^{\mathrm{b}}$ School of Forestry and Resource Conservation, College of Bio-Resources and Agriculture, National Taiwan University, No. 1, Sec. 4, Roosevelt Road, Taipei 10617, Taiwan
}

\section{A R T I C L E I N F O}

\section{Article history:}

Received 6 May 2008

Received in revised form

26 July 2008

Accepted 28 July 2008

Available online 5 March 2009

\section{Keywords:}

Copper-based preservative

Leaching

Metal corrosion

Termite resistance

\begin{abstract}
A B S T R A C T
Health-awareness and concern for the environment have resulted in voluntary removal of chromated copper arsenate (CCA) from wood preservatives in residential applications worldwide. Copper-based preservatives have been formulated as replacements, but these may not provide a permanent solution to all of the related problems, including copper contamination of aquatic environments and corrosion of fasteners. In this study, the copper retention (before and after the leaching process) of five softwood specimens vacuum-treated with alkaline copper quaternary (ACQ) and copper azole (CA) at three target retention levels was investigated by X-ray fluorescence studies. The metal corrosion and termite (Coptotermes formosanus) resistance of treated specimens were studied under laboratory conditions. Except for treated Japanese larch wood, the copper retention levels of the other wood specimens were able to meet the target copper retention values (use classes 2-4) in Chinese National Standard 3000. The copper leaching rates were $6.92-19.54 \%$ for ACQ-treated wood and 9.38-22.46\% for CA-treated wood. The metal corrosion rates of iron nails due to corrosion tests (CNS 6717) were influenced significantly by the $1.2 \%$ ACQ and 1.2\% CA treatments; whereas the metal corrosion rates of zinc-galvanized steel nails were less than 2 and could meet the tested standard. Even though the ACQ and CA treatments caused higher copper leaching rates from the treated specimens, they also increased termite mortalities and reduced the mass loss significantly after termite-resistance tests (JIS K 1571).
\end{abstract}

(C) 2009 Published by Elsevier Ltd.

\section{Introduction}

Biodegradation of wood by termites is recognized as one of the most serious problems for wood utilization in countries such as Taiwan, Japan, and parts of the U.S. (Cheng et al., 2007). Many toxic wood preservatives were used in the past in attempts to minimize termite damage. Recognition of risks for human health and potential damage of the environment have prompted changes in the types of preservatives used commercially in recent years. The use of preservatives that include arsenic, chromium, and other heavy metals has decreased in most European countries and in North America (Green and Clausen, 2005; Humar et al., 2006b).

Some alternative methods, including chemical modification and the use of arsenic/chromium-free preservatives, have been developed to enhance the durability of wood without the use of conventional toxic biocides. Chemical modification is accomplished by treating the wood with selected chemicals that modify the cell wall wood polymers without leaving toxic residues within the

\footnotetext{
* Corresponding author. Tel.: +8862 33664641; fax: +886223686335.

E-mail address: tmj@ntu.edu.tw (M.-J. Tsai).
}

wood (Papadopoulos et al., 2002). The use of chemical modification to stabilize wood against the activities of decay organisms has been the subject of numerous studies (Rowell, 1983; Hon, 1996; Papadopoulos et al., 2008). Arsenic/chromium-free alternatives based on copper compounds have also been introduced recently as alternative chemicals, because copper exhibits good biocidal activity (Nicholas and Schultz, 1997). Some of these new preservative systems include alkaline copper quaternary (ACQ), copper azole (CA), ammoniacal copper citrate (CC), copper dimethyldithio-carbamate (CDDC), and Cu-HDO (bis-( $N$-cyclohexyldiazeniumdioxy)-copper) (Cao and Kamdem, 2004; Lebow et al., 2005). There have been some reports about the properties of penetration, retention, leaching, and resistance to fungi and termites, as well as long-term field testing of some softwoods and hardwoods treated with these new preservatives (Creffield et al., 1996; Slahor et al., 1997; Hassler et al., 1999; Drysdale et al., 2000; Fox et al., 2000; Morris et al., 2002; Terziev, 2002; Rhatigan et al., 2004; Temiz et al., 2004, 2005; Lebow et al., 2005; Arango et al., 2006; Humar et al., 2006a; Yildiz, 2007).

However, copper-based preservatives may not provide a permanent solution to all related problems; some of these issues include concern over copper in aquatic environments and corrosion 
of fasteners (Jin et al., 1992; Anon., 1994; Lebow, 1996; Stook et al., 2005; Arango et al., 2006; Temiz et al., 2006). In this study, copper retention (before and after the leaching process) of five softwood specimens vacuum-treated with ACQ and CA at three target retention levels was investigated by X-ray fluorescence studies. The metal corrosion and termite (Coptotermes formosanus) resistance of treated specimens were studied under laboratory conditions. These results can provide information for estimating the applicability of copper-based preservatives in architectural design.

\section{Materials and methods}

\subsection{Wood specimens and preservative treatments}

Specimens, measuring $20 \mathrm{~mm}$ (radial) $\times 20 \mathrm{~mm}$ (tangential) $\times 10 \mathrm{~mm}$ (longitudinal), were cut from sapwood portions of Taiwania (Taiwania cryptomerioides, average density: $325 \mathrm{~kg} \mathrm{~m}^{-3}$ ), Japanese cedar (Cryptomeria japonica, average density: $483 \mathrm{~kg} \mathrm{~m} \mathrm{~m}^{-3}$ ), China fir (Cunninghamia lanceolata, average density: $372 \mathrm{~kg} \mathrm{~m}^{-3}$ ), Japanese larch (Larix leptolepis, average density: $566 \mathrm{~kg} \mathrm{~m}^{-3}$ ), and Western hemlock (Tsuga heterophylla, average density: $484 \mathrm{~kg} \mathrm{~m}^{-3}$ ). Before treatment, all wood specimens were kept at $20{ }^{\circ} \mathrm{C}$ and $65 \%$ relative humidity (RH) for 2 weeks. All specimens were numbered and weighed to the nearest $0.01 \mathrm{~g}$. The specimens were free of knots and visible concentration of resins, and showed no visible evidence of infection by mold, stain, or wood-degrading fungi.

The specimens were vacuum-treated with two different copperbased preservatives at various concentrations: $0.3 \%, 0.6 \%$, and $1.2 \%$ alkaline copper quaternary (ACQ-A; Koshii Preserving Co., Japan; including $7.2 \%$ alkylbenzyldimethyl ammonium chloride (C8-C18) and $9.2 \%$ copper oxide) and copper azole (Wolman CA-B; Arch Wood Protection; including $10.0 \%$ copper $(\mathrm{w} / \mathrm{w})$ and $0.40 \%$ azole (Tebuconazole) $(\mathrm{w} / \mathrm{w}))$. The specimens were placed in a desiccator and subjected to a $700 \mathrm{~mm} \mathrm{Hg}$ vacuum for $20 \mathrm{~min}$. The treatment solution was introduced and the vacuum was released. After $30 \mathrm{~min}$, the specimens were removed from the solution, wiped lightly to remove preservative solution from the surface, and immediately weighed to the nearest $0.01 \mathrm{~g}$. These specimens were stored in plastic bags at $20^{\circ} \mathrm{C}$ for 2 weeks before analyses for copper retention.

\subsection{Leaching of treated wood specimens}

The leaching test was conducted according to Chinese National Standard 6717 (2000) to reproduce the effect of weathering. The procedure involves immersing the wood specimens in distilled water, stirring with a magnetic follower $(400-450 \mathrm{rpm})$ at $27^{\circ} \mathrm{C}$ for $8 \mathrm{~h}$, followed by drying at $60{ }^{\circ} \mathrm{C}$ for $16 \mathrm{~h}$. This cycle was repeated 10 times. After each leaching cycle, the water was replaced with fresh distilled water at a ratio of 10 volumes of water to 1 volume of wood. After the leaching process, the specimens were stored in plastic bags at $20^{\circ} \mathrm{C}$ for 2 weeks before analyses for copper retention.

\subsection{Analyses of treated wood for copper retention}

After the fixation period and leaching process, copper retention (in $\mathrm{kg} \mathrm{m}^{-3}$ ) was assessed according to Chinese National Standard 14730 (2003) with an energy dispersive X-ray fluorescence spectrometer (ED-XRF, Oxford Lab-X 3500 analyzer, UK). The leaching rate of copper (formula (1)) in the wood specimens was calculated on the basis of the initial amount of copper in the specimens.

Leaching rate of $\operatorname{copper}(\%)=\frac{R_{1}-R_{2}}{R_{1}} \times 100$ where $R_{1}$ and $R_{2}$ represent the average copper retention (before and after the leaching process) of wood specimens investigated by $\mathrm{X}$-ray fluorescence studies, respectively.

\subsection{Metal corrosion tests}

Iron nails and hot dip, zinc-galvanized steel nails, both $38 \mathrm{~mm}$ long and with a diameter of $2.35 \mathrm{~mm}$, and Japanese cedar wood specimens measuring $20 \mathrm{~mm}$ (radial) $\times 20 \mathrm{~mm}$ (tangential) $\times 45 \mathrm{~mm}$ (longitudinal) were selected for metal corrosion tests of wood treated with copper-based preservatives, according to the method described in Chinese National Standard 6717 (2000). Two nails (both iron or both galvanized steel) were pushed into the cross section of the vacuum-treated wood specimens. The specimens were conditioned at $40{ }^{\circ} \mathrm{C}$ and $97 \% \mathrm{RH}$ for 10 days. The mass loss of the nails due to these corrosion tests was calculated as the difference between the initial weight and the final weight of the nails after withdrawal from the wood and removal of the rust with $10 \%$ ammonium citrate. The metal corrosion rate was evaluated using the following formula:

Metal corrosion rate $(\%)=\frac{M_{2}}{M_{1}} \times 100$

where $M_{1}$ and $M_{2}$ represent the average mass loss rates of the nails after withdrawal from the wood without and with preservative treatment, respectively. Metal corrosion rate is considered to be the important quantity index of the wood preservative and must be less than 2 .

\subsection{Termite-resistance tests}

Untreated control and treated specimens (without and after the leaching process) were exposed to the subterranean termite $C$. formosanus Shiraki according to the method detailed in Japanese Industrial Standard K 1571 (2004). An acrylic cylinder (80 mm in diameter, $60 \mathrm{~mm}$ in height) with the lower end sealed with a 5mm-thick hard plaster was used as a container. The test specimen was placed at the center of the plaster bottom of the test container. A total of 150 worker termites collected from a laboratory colony of National Taiwan University were introduced into each test container together with 15 termite soldiers. Five wood specimens per treatment were exposed to the termites. The assembled containers were set on damp cotton pads to supply water to the specimens, and kept at $28{ }^{\circ} \mathrm{C}$ and $>85 \% \mathrm{RH}$ in darkness for 3 weeks. The mass loss of the specimens due to termite attack was calculated as the difference between the initial weight and final oven-dried ( $60{ }^{\circ} \mathrm{C}, 3$ days) weights of the specimens after the debris from the termite attack was cleaned off. Termite mortality was also recorded.

\section{Results and discussion}

\subsection{Copper retention of treated wood specimens after the leaching process}

In this study, the designated conditions for exposure of treated wood were use classes $2-4$ according to Chinese National Standard 3000 (2001): (1) leaching from treated wood used indoors at 70\% RH (use class 2); and (2) treated wood used outdoors was exposed indirectly (use class 3 ) or directly (use class 4 ) to weathering and not in contact with the ground or water. The principal agent for causing leaching from wood in use class 4 is rainfall. Rainfall on the treated wood could produce leaching, which runs off into surface water and/or soil. Wood exposed in an above-ground situation is subjected to the intermittent wetting of rainfall and the drying of the wood surface between rainfall events. These wetting and drying 
Table 1

Copper retention (before and after the leaching process) of five softwood specimens investigated by X-ray fluorescence studies.

\begin{tabular}{|c|c|c|c|c|c|c|c|}
\hline \multirow[t]{2}{*}{ Treatment solution } & \multirow[t]{2}{*}{ Leaching treatment } & \multicolumn{5}{|c|}{ Copper retention $\left(\mathrm{kg} \mathrm{m}^{-3}\right)$, mean (SD) } & \multirow[t]{2}{*}{ Suggested copper retention in CNS $3000\left(\mathrm{~kg} \mathrm{~m}^{-3}\right)$} \\
\hline & & China fir & Western hemlock & Japanese cedar & Japanese larch & Taiwania & \\
\hline $0.3 \%$ ACQ & $\begin{array}{l}\text { Unleached } \\
\text { Leached }\end{array}$ & $\begin{array}{l}1.58(0.12) \\
1.39(0.14)\end{array}$ & $\begin{array}{l}1.30(0.18) \\
1.16(0.26)\end{array}$ & $\begin{array}{l}1.61(0.12) \\
1.46(0.16)\end{array}$ & $\begin{array}{l}0.71(0.08) \\
0.59(0.14)\end{array}$ & $\begin{array}{l}1.59(0.14) \\
1.48(0.19)\end{array}$ & 1.04 (class 2) \\
\hline $0.6 \%$ ACQ & $\begin{array}{l}\text { Unleached } \\
\text { Leached }\end{array}$ & $\begin{array}{l}2.93(0.26) \\
2.49(0.35)\end{array}$ & $\begin{array}{l}2.43(0.32) \\
2.12(0.68)\end{array}$ & $\begin{array}{l}3.13(0.28) \\
2.79(0.45)\end{array}$ & $\begin{array}{l}1.54(0.12) \\
1.24(0.20)\end{array}$ & $\begin{array}{l}2.77(0.37) \\
2.46(0.85)\end{array}$ & 2.08 (class 3) \\
\hline $1.2 \%$ ACQ & $\begin{array}{l}\text { Unleached } \\
\text { Leached }\end{array}$ & $\begin{array}{l}5.99(0.44) \\
4.91(0.85)\end{array}$ & $\begin{array}{l}4.92(0.54) \\
4.18(0.98)\end{array}$ & $\begin{array}{l}6.15(0.57) \\
5.41(0.88)\end{array}$ & $\begin{array}{l}2.61(0.14) \\
2.10(0.68)\end{array}$ & $\begin{array}{l}6.02(0.24) \\
5.12(0.90)\end{array}$ & 4.15 (class 4 ) \\
\hline $0.3 \% \mathrm{CA}$ & $\begin{array}{l}\text { Unleached } \\
\text { Leached }\end{array}$ & $\begin{array}{l}1.37(0.24) \\
1.22(0.56)\end{array}$ & $\begin{array}{l}1.26(0.22) \\
1.09(0.36)\end{array}$ & $\begin{array}{l}1.28(0.12) \\
1.16(0.18)\end{array}$ & $\begin{array}{l}0.78(0.06) \\
0.67(0.24)\end{array}$ & $\begin{array}{l}1.47(0.20) \\
1.32(0.60)\end{array}$ & 1.04 (class 2) \\
\hline $0.6 \% \mathrm{CA}$ & $\begin{array}{l}\text { Unleached } \\
\text { Leached }\end{array}$ & $\begin{array}{l}2.53(0.28) \\
2.22(0.68)\end{array}$ & $\begin{array}{l}2.45(0.46) \\
2.09(0.75)\end{array}$ & $\begin{array}{l}2.85(0.20) \\
2.54(0.62)\end{array}$ & $\begin{array}{l}1.29(0.14) \\
1.05(0.66)\end{array}$ & $\begin{array}{l}2.61(0.16) \\
2.22(0.72)\end{array}$ & 2.08 (class 3) \\
\hline $1.2 \% \mathrm{CA}$ & $\begin{array}{l}\text { Unleached } \\
\text { Leached }\end{array}$ & $\begin{array}{l}5.04(1.06) \\
4.31(0.96)\end{array}$ & $\begin{array}{l}4.95(0.40) \\
4.20(1.20)\end{array}$ & $\begin{array}{l}5.79(0.64) \\
4.93(1.24)\end{array}$ & $\begin{array}{l}2.76(0.18) \\
2.14(0.85)\end{array}$ & $\begin{array}{l}5.18(0.56) \\
4.34(1.48)\end{array}$ & 4.15 (class 4 ) \\
\hline
\end{tabular}

Values in parenthesis are standard deviations.

cycles were simulated under laboratory conditions. We assumed that leaching obtained by exposure to rainfall is identical with leaching obtained by immersion in water. According to CNS 3000, ACQ and CA treatments were not appropriate when the treated wood was constantly in contact with the ground, fresh water, or seawater (use class 5 ).

Table 1 shows the copper retention of five softwood specimens at three target retention levels after vacuum-treatment with ACQ and CA. Except for treated Japanese larch wood, the copper retentions of the other wood specimens were able to meet the target copper retention values (use classes 2-4) in CNS 3000. The treated Japanese larch wood was able to meet the target copper retention values (use classes 2 and 3) in CNS 3000 because of resins in the tracheids of Japanese larch. Generally, the copper retentions of treated specimens increase with an increase of preservative concentration. A high coefficient of relationship $(r=0.9763)$ between copper retention and preservative concentration was found. Taking specimen density into consideration, there was a negative linear relationship $(r=0.7074)$ between copper retention of treated specimens and density of the wood.

Table 1 also indicated copper retention of treated wood specimens after the leaching process. Except for treated Japanese larch wood, the copper retention of the other wood specimens after the leaching process met the target copper retention values for use classes 2-4 in CNS 3000 (Table 1). After the leaching process, the treated Japanese larch wood could meet the target copper retention value only for use classes 2 and 3 in CNS 3000. For all ACQ- and CAtreated wood specimens, the copper leaching rates were 6.92$19.54 \%$ and $9.38-22.46 \%$, respectively. Generally, the copper leaching rates of treated specimens increased with increased concentration of treated preservative, possibly because of better copper fixation when the wood was treated with lower concentrations of preservatives.

These results support the findings reported by Anon. (1990, 1994) and Jin et al. (1992). Anon. (1994) showed that copper leaching rates were $17.4 \%$ from ACQ-B-treated wood and $15.4 \%$ from ACQ-D-treated wood (both retentions: $6.4 \mathrm{~kg} \mathrm{~m}^{-3}$ ) as measured by a soil-bed test, whereas the copper leaching rate (10-14\%) decreased due to an above-ground depletion test (Jin et al., 1992; Anon., 1994). Moreover, the leaching rate increased from that of ACQ-B-treated wood, with a higher retention of $9.6 \mathrm{~kg} \mathrm{~m}^{-3}$ (Jin et al., 1992), and decreased with a lower retention of $0.4 \mathrm{~kg} \mathrm{~m}^{-3}$ (Anon., 1990). Furthermore, Temiz et al. (2006) found the greatest loss of copper from wood treated with ACQ-1900 and ACQ-2200 in the first periods of the leaching process. The percentage of copper leached from the wood treated with the alternative copper-based preservatives was greater than that from the CCA-treated wood.

By using various leaching procedures, including the toxicity characteristic leaching procedure, the synthetic precipitation leaching procedure, the synthetic seawater leaching procedure, and the deionized water leaching procedure, Stook et al. (2005) found that $15-40 \%$ of copper leached from ACQ-D-treated wood and $18-$ $39 \%$ of copper leached from CBA-A-treated wood, respectively. The average copper leaching rates from treated wood, in decreasing order, were toxicity characteristic leaching procedure $>$ synthetic seawater leaching procedure $>$ synthetic precipitation leaching procedure $>$ deionized water leaching procedure. The copper leaching rate after the deionized water leaching procedure was close to our results after the distilled water leaching procedure.

\subsection{Metal corrosion}

Fig. 1 shows the metal corrosion rate of wood treated with ACQ and CA. The results indicate that the metal corrosion rate of the iron nails due to corrosion was influenced significantly by the treatment with $1.2 \%$ ACQ and $1.2 \%$ CA (metal corrosion rate $>2$ ). This is because serious metal corrosion may be caused by ammonia and chloride in the preservatives tested (Lin and Chen, 2004; Ayrilmis, 2007). Ayrilmis (2007) also pointed out that waterborne inorganic salts may be hygroscopic and corrosion metal fixtures in treated wood may be increased. The metal corrosion rates of the iron nails

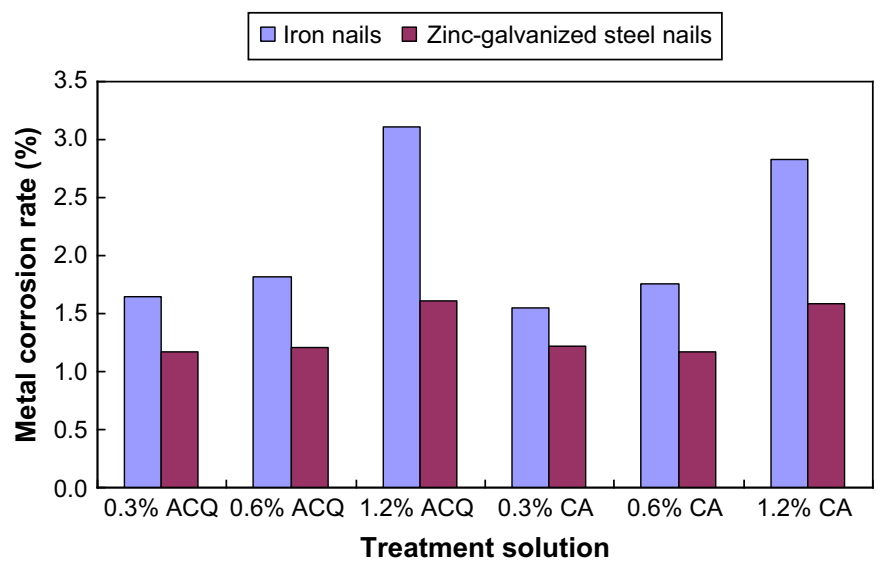

Fig. 1. Metal corrosion rate of wood treated with alkaline copper quaternary (ACQ) and copper azole (CA). 
Table 2

Mass losses (\%) in wood specimens exposed to termite.

\begin{tabular}{|c|c|c|c|c|c|c|}
\hline \multirow[t]{2}{*}{ Treatment solution } & \multirow[t]{2}{*}{ Leaching treatment } & \multicolumn{5}{|c|}{ Mass loss (\%), mean (SD) } \\
\hline & & China fir & Western hemlock & Japanese cedar & Japanese larch & Taiwania \\
\hline Untreated control & & $12.02(1.44)$ & $13.06(2.08)$ & $12.98(1.25)$ & $13.94(1.96)$ & $13.14(0.94)$ \\
\hline \multirow[t]{2}{*}{$0.3 \%$ ACQ } & Unleached & $0.60(0.23)$ & $0.95(0.14)$ & $0.87(0.15)$ & $0.85(0.32)$ & $0.99(0.16)$ \\
\hline & Leached & $3.16(0.60)$ & $2.60(0.78)$ & $3.21(0.78)$ & $1.41(0.18)$ & $3.18(0.65)$ \\
\hline \multirow[t]{2}{*}{$0.6 \%$ ACQ } & Unleached & $0.55(0.15)$ & $0.74(0.25)$ & $0.80(0.24)$ & $0.85(0.16)$ & $0.66(0.20)$ \\
\hline & Leached & $0.98(0.38)$ & $0.98(0.26)$ & $0.88(0.32)$ & $1.02(0.36)$ & $0.76(0.25)$ \\
\hline \multirow[t]{2}{*}{$1.2 \%$ ACQ } & Unleached & $0.29(0.02)$ & $0.28(0.04)$ & $0.78(0.25)$ & $0.45(0.12)$ & $0.27(0.04)$ \\
\hline & Leached & $0.32(0.05)$ & $0.38(0.14)$ & $0.75(0.36)$ & $0.68(0.40)$ & $0.36(0.08)$ \\
\hline \multirow[t]{2}{*}{$0.3 \% \mathrm{CA}$} & Unleached & $0.84(0.24)$ & $1.45(0.25)$ & $0.89(0.18)$ & $0.93(0.64)$ & $0.84(0.42)$ \\
\hline & Leached & $2.74(0.56)$ & $2.55(0.46)$ & $2.55(0.67)$ & $1.56(0.36)$ & $2.93(0.60)$ \\
\hline \multirow[t]{2}{*}{$0.6 \% \mathrm{CA}$} & Unleached & $0.85(0.14)$ & $0.72(0.17)$ & $0.86(0.32)$ & $0.99(0.27)$ & $0.77(0.19)$ \\
\hline & Leached & $1.20(0.38)$ & $1.36(0.58)$ & $0.90(0.48)$ & $1.04(0.36)$ & $0.88(0.29)$ \\
\hline \multirow[t]{2}{*}{$1.2 \% \mathrm{CA}$} & Unleached & $0.45(0.09)$ & $0.42(0.14)$ & $0.90(0.26)$ & $0.72(0.18)$ & $0.56(0.12)$ \\
\hline & Leached & $0.54(0.09)$ & $0.48(0.22)$ & $0.88(0.24)$ & $0.88(0.16)$ & $0.86(0.20)$ \\
\hline
\end{tabular}

Values in parenthesis are standard deviations.

were $1.65-3.11 \%$ for ACQ-treated specimens, and $1.55-2.83 \%$ for CAtreated specimens.

The metal corrosion rates of the zinc-galvanized nails after the corrosion tests were less than 2 (Fig. 1). The rates showed no significant difference among specimens treated with $0.3 \%$ ACQ $0.6 \%$ ACQ $0.3 \%$ CA, and 0.6\% CA (1.17-1.22\%). However, a significant difference was found between $1.2 \%$-ACQ- (or $1.2 \%$-CA-)treated specimens (1.59-1.62\%) and the other specimens.

The metal corrosion rates of the zinc-galvanized steel nails were lower than those of the iron nails for the same preservative at the same concentration. This suggests that the use of zinc-galvanized steel nails is preferred for connecting ACQ- and CA-treated woods.

\subsection{Termite resistance of untreated specimens}

The termite-resistance tests showed that untreated Japanese larch suffered the greatest mean mass loss (mean 13.94\%; Table 2) and had the lowest termite mortality (9.5\%; Table 3) (a positive relationship [ $r=0.6442]$ between specific gravity and mass loss, but a negative correlation between termite mortality and mass loss $[r=0.6923]$, and between specific gravity and termite mortality $[r=0.5970])$. The hypothesis that woods with a higher specific gravity have a greater natural resistance to degradation by termites appears contradictory to the results of our study. However, the density is not the sole factor affecting the durability of wood. A study carried out by Peralta et al. (2004), which focused on wood consumption rates of different forest species by termites under field conditions, did not find a strong correlation between wood density and termite resistance. Chang et al. (1999) also indicated that extractives have a significant effect on the durability of wood, and certain extractives from wood tissues can provide protection against harmful insects. In a study of Arango et al. (2006), six hardwoods and six softwoods were evaluated for their ability to resist termite damage by Reticulitermes flavipes. Mass loss versus specific gravity showed an inverse correlation in tropical hardwood species, but a slightly positive correlation in native softwood species. Similar results were also found by Esenther (1997) in a study of the natural resistance of 21 native and exotic woods. However, observation of the mean mass loss and mean termite mortality showed no statistically significant difference between the sets of specimens in this study. It appeared that there was a greater percentage of termite deaths associated with woods of a lower specific gravity. However, these results are limited to the wood species chosen for the experiment.

\subsection{Termite resistance of treated specimens}

Even at low retention values, ACQ- and CA-treated specimens showed lower mass loss and greater termite mortality in comparison to those shown by the untreated specimens. All treated

Table 3

Termite mortalities in wood specimens exposed to termite.

\begin{tabular}{|c|c|c|c|c|c|c|}
\hline \multirow[t]{2}{*}{ Treatment Solution } & \multirow[t]{2}{*}{ Leaching treatment } & \multicolumn{5}{|c|}{ Termite mortality (\%), mean (SD) } \\
\hline & & China fir & Western hemlock & Japanese cedar & Japanese larch & Taiwania \\
\hline \multirow{3}{*}{$\begin{array}{l}\text { Untreated control } \\
0.3 \% \text { ACQ }\end{array}$} & & $26.5(9.8)$ & $10.8(7.2)$ & $28.3(12.5)$ & $9.5(8.4)$ & $22.0(7.5)$ \\
\hline & Unleached & $72.0(9.0)$ & $70.8(12.0)$ & $50.8(4.6)$ & $60.8(6.9)$ & $72.5(11.0)$ \\
\hline & Leached & $52.5(7.9)$ & $55.3(9.7)$ & $40.0(12.8)$ & $40.8(10.4)$ & $48.3(8.9)$ \\
\hline \multirow[t]{2}{*}{$0.6 \%$ ACQ } & Unleached & $89.8(10.0)$ & $93.3(4.7)$ & $69.5(5.0)$ & $77.3(15.5)$ & $98.5(0.1)$ \\
\hline & Leached & $79.8(15.6)$ & $82.3(14.9)$ & $70.3(12.8)$ & $75.0(13.8)$ & $85.2(12.1)$ \\
\hline \multirow[t]{2}{*}{$1.2 \%$ ACQ } & Unleached & $87.3(11.3)$ & $99.5(0.2)$ & $78.0(9.8)$ & $85.0(9.2)$ & $99.5(0.2)$ \\
\hline & Leached & $87.7(10.1)$ & $98.5(0.5)$ & $81.0(6.5)$ & $83.5(13.5)$ & $99.5(0.3)$ \\
\hline \multirow[t]{2}{*}{$0.3 \%$ CA } & Unleached & $72.0(10.5)$ & $68.0(7.8)$ & $63.8(7.8)$ & $61.5(16.5)$ & 76.0 (16.7) \\
\hline & Leached & $53.8(14.0)$ & $51.3(8.0)$ & $48.8(12.1)$ & $45.8(13.0)$ & $60.0(11.0)$ \\
\hline \multirow[t]{2}{*}{$0.6 \% \mathrm{CA}$} & Unleached & $88.3(7.6)$ & $94.5(4.2)$ & $78.5(9.8)$ & $72.8(12.8)$ & $96.0(3.6)$ \\
\hline & Leached & $82.8(16.4)$ & $88.3(10.2)$ & $78.0(14.4)$ & $70.0(19.6)$ & $89.3(8.8)$ \\
\hline \multirow[t]{2}{*}{$1.2 \% \mathrm{CA}$} & Unleached & $97.3(1.2)$ & $93.5(5.8)$ & $99.0(0.6)$ & $99.8(0.1)$ & $99.5(0.3)$ \\
\hline & Leached & $97.0(1.8)$ & $90.8(7.8)$ & $98.5(1.2)$ & $98.3(0.5)$ & $98.5(0.5)$ \\
\hline
\end{tabular}

Values in parenthesis are standard deviations. 
specimens had significantly less mass loss and greater termite mortality than untreated specimens. The treatments with ACQ and CA appeared to improve the resistance of wood to termite attack. Even though the leaching process caused higher leaching rates of copper from the treated specimens, ACQ and CA treatments also increased termite mortality significantly and reduced the mass loss.

We examined the relationship between termite mortality, mass loss, and specific gravity using linear statistical analysis. According to this test, the mass loss and the termite mortality of treated specimens were inversely associated $(r=0.5972)$. The rate of termite mortality and specific gravity were also inversely related $(r=0.3292)$, while mass loss had a marginally positive association with specific gravity $(r=0.2629)$.

\section{Conclusions}

Evaluation of leachability, metal corrosion, and termite resistance of wood treated with copper-based preservative is becoming increasingly important in the wood preservation industry, because there has been a great deal of focus on preservative contamination of aquatic environments and corrosion of fasteners in residential applications. In this study, copper retention (before and after the leaching process) of five softwood specimens vacuum-treated with ACQ and CA at three target retention levels was investigated by $\mathrm{X}$-ray fluorescence studies. The metal corrosion and termite resistance of treated specimens were studied under laboratory conditions. The results indicate that the copper retentions of treated specimens increase with an increase of preservative concentration. A high coefficient of relationship $(r=0.9763)$ between copper retention and preservative concentration was found. Taking specimen density into consideration, there was a negative linear relationship $(r=0.7074)$ between copper retention of treated specimens and density of the wood. For all ACQ- and CA-treated wood specimens, the copper leaching rates were $6.92-19.54 \%$ and $9.38-22.46 \%$, respectively. Generally, the copper leaching rates of treated specimens increased with increased concentration of treated preservative.

The metal corrosion rates of the zinc-galvanized steel nails were lower than those of the iron nails for the same preservative at the same concentration. The rates of the iron nails due to corrosion were $1.65-3.11 \%$ for ACQ-treated specimens, and 1.55-2.83\% for CAtreated specimens. The rates were influenced significantly by the treatments with $1.2 \%$ ACQ and $1.2 \%$ CA (metal corrosion rate $>2 \%$ ). The metal corrosion rates of the zinc-galvanized nails after the corrosion tests were less than 2 . The rates showed no significant difference among specimens treated with 0.3\% ACQ, 0.6\% ACQ 0.3\% CA, and $0.6 \%$ CA (1.17-1.22\%). However, a significant difference was found between 1.2\% ACQ- (or 1.2\% CA-)treated specimens (1.59$1.62 \%$ ) and the other specimens.

After the leaching process, treatment with ACQ and CA also increased termite mortality significantly and reduced the mass loss. However, the effects of wood treatments on human health and the environment need to be assessed by all aspects of wood preservatives. Further studies of preservative fixation and metal corrosion of copper in wood treated with copper-based preservatives should be conducted in the future with concern for human health, the environment and architectural aspects.

\section{Acknowledgements}

The authors wish to thank the Forestry Bureau, Council of Agriculture, Executive Yuan, Taiwan, R.O.C., for financial support under grant 96AS-12.3.5-FB-e1(1).

\section{References}

Anon., 1990. Attachment I. Information presented to American Wood Preservers' Association Committee P-4 on ammoniacal copper/quaternary ammonium compound (ACQ) preservative systems. In: Proceedings of American Wood Preservers' Association, vol. 86, pp. 229-236.

Anon., 1994. ACQ Type-D. Proposal to the AWPA Technical Committees to Include ACQ Type D in Standards P5, C1, C2, C15, C9, and M6. Chemical Specialties, Inc., Charlotte, NC.

Arango, R.A., Green, F., Hintz, K., Lebow, P.K., Miller, R.B., 2006. Natural durability of tropical and native woods against termite damage by Reticulitermes flavipes (Kollar). International Biodeterioration \& Biodegradation 57, 146-150.

Ayrilmis, N., 2007. Effect of fire retardants on internal bond strength and bond durability of structural fiberboard. Building and Environment 42, 1200-1206.

Cao, J., Kamdem, D.P., 2004. Moisture adsorption characteristics of copper-ethanolamine (Cu-EA) treated southern yellow pine (Pinus spp.). Holzforschung 58, 32-38.

Chang, S.T., Wang, S.Y., Wu, C.L., Su, Y.C., Kuo, Y.H., 1999. Antifungal compounds in the ethyl acetate soluble fraction of the extractives of Taiwania (Taiwania cryptomerioides Hayata) heartwood. Holzforschung 53, 487-490.

Cheng, S.S., Chang, H.T., Wu, C.L., Chang, S.T., 2007. Anti-termitic activities of essential oils from coniferous trees against Coptotermes formosanus. Bioresource Technology 98, 456-459.

Chinese National Standard CNS 14730, 2003. Method of Test for Absorption of Wood Preservatives. Bureau of Standards, Metrology and Inspection, Ministry of Economic Affairs (MOEA), Taipei, Taiwan.

Chinese National Standard CNS 3000, 2001. Preservative Treatments of Woods by Pressure Processes. Bureau of Standards, Metrology and Inspection, Ministry of Economic Affairs (MOEA), Taipei, Taiwan.

Chinese National Standard CNS 6717, 2000. Qualitative Standards and Testing Methods of Wood Preservatives. Bureau of Standards, Metrology and Inspection, Ministry of Economic Affairs (MOEA), Taipei, Taiwan.

Creffield, J.W., Drysdale, J.A., Chew, N., 1996. In-ground evaluation of a copper azole wood preservative (Tanalith E) at a tropical Australian test site. In: Proceedings of the IRG 27th Annual Meeting, 19-24 May 1996, Guadeloupe, France, IRG/WP 96-30100.

Drysdale, J.A., Hedley, M.E., Loh, E., Hong, L.T., 2000. Comparative performance of copper azole and copper-chrome-arsenate treated rubber wood in Australian Malaysian and New Zealand tests sites. In: Proceedings of the IRG 31st Annual Meeting, 14-19 May 2000, Kona Surf, Hawaii, IRG/WP 00-30213.

Esenther, G.R., 1997. Nutritive supplement method to evaluate resistance of natural or preservative wood to subterranean termites. Journal of Economic Entomology 70, 341-346.

Fox, R.F., Pasek, E.A., Patel, J., 2000. Laboratory termite testing of copper boron tebuconazole. In: Proceedings of the IRG 31st Annual Meeting, 14-19 May 2000, Kona Surf, Hawaii, IRG/WP 00-20192.

Green III, F., Clausen, C.A., 2005. Copper tolerance of brown-rot fungi: oxalic acid production in southern pine treated with arsenic-free preservatives. International Biodeterioration \& Biodegradation 56, 75-79.

Hassler, C.C., Slahor, J.J., Gardner, D.J., 1999. A comparison of the treatability of southern yellow pine to five Appalachian hardwoods. Forest Products Journal 49, 89-93.

Hon, D.N.S., 1996. Chemical Modification of Lignocellulosic Materials. Marcel Dekker, Inc., New York, pp. 159-183.

Humar, M., Bucar, B., Pohleven, F., 2006a. Brown-rot decay of copper-impregnated wood. International Biodeterioration \& Biodegradation 58, 9-14.

Humar, M., Peek, R.D., Jermer, J., 2006b. Regulations in the European Union with emphasis on Germany, Sweden, and Slovenia. In: Solo-Gabriele, $\mathrm{H}$. Townsend, T., Taylor, Francis (Eds.), Environmental Impacts of Preservativetreated Wood, Boca Raton, pp. 37-57.

Japanese Industrial Standard JIS K 1571, 2004. Test Methods for Determining the Effectiveness of Wood Preservatives and Their Performance Requirements. Japanese Standard Association (in Japanese).

Jin, L., Archer, K., Preston, A.F., 1992. Depletion and biodeterioration studies with developmental wood preservative formulations. In: Proceedings of American Wood Preservers' Association, vol. 88, pp. 108-125.

Lebow, S., 1996. Leaching of Wood Preservative Components and Their Mobility in the Environment. Summary of Pertinent Literature. Gen. Tech. Rep. FPL-GTR-93. U.S. Department of Agriculture, Forest Service, Forest Products Laboratory, Madison, WI, 36 pp.

Lebow, S.T., Halverson, S.A., Hatfield, C.A., 2005. Treatability of Underutilized Northeastern Species with CCA and Alternative Wood Preservatives. Research note FPL-RN-0300. Forest Products Laboratory, USA, 7 pp.

Lin, Y.L., Chen, K.K., 2004. Development of wood preservatives in the future. Bimonthly Newsletter of the Taiwan Forestry Research Institute 11 (6), 23-24.

Morris, P.I., McFarling, S.M., Zahora, A.R., 2002. Treatability of refractory species with amine and amine/ammoniacal formulations of ACQ (Processes). Forest Products Journal 52, 37-42.

Nicholas, D.D., Schultz, T.P., 1997. Comparative Performance of Several Ammoniacal Copper Preservative Systems. International Research Group on Wood Preservation, Stockholm, Sweden. IRG/WP 97-30151.

Papadopoulos, A.N., Duquesnoy, P., Cragg, S.M., Pitman, A.J., 2008. The resistance of wood modified with linear chain carboxylic acid anhydrides to attack by the marine wood borer Limnoria quadripunctata Holthius. International Biodeterioration \& Biodegradation 61, 199-202. 
Papadopoulos, A.N., Hale, M.D., Hill, C.A.S., 2002. Efficacy of Linear Chain Carboxylic Acid Anhydrides as Wood Protecting Chemicals. International Research Group on Wood Preservation. Document Number IRG/WP 02-30295.

Peralta, R.C.G., Menezes, B., Carvalho, A.G., Aguiar-Menezes, E., 2004. Wood consumption rates of forest species by subterranean termites (Isoptera) under field conditions. Sociedade de Investigações Florestais 28, 283-289.

Rhatigan, R., Freitag, C., El-Kasmi, S., Morrell, J.J., 2004. Preservative treatment of Scots pine and Norway spruce. Forest Products Journal 54, 91-94.

Rowell, R.M., 1983. Chemical modification of wood. Forest Products Abstracts 6 , 366-382.

Slahor, J.J., Hassler, C.C., Degroot, R.C., Gardner, D.J., 1997. Preservative treatment evaluation with CCA and ACQ-B of four Appalachian wood species for use in timber transportation structures. Forest Products Journal 47, 33-42.

Stook, k., Tolaymat, T., Ward, M., Dubey, B., Townsend, T., Gabriele, H.S., Bitton, G., 2005. Relative leaching and aquatic toxicity of pressure-treated wood products using batch leaching tests. Environmental Science \& Technology 39, 155-163.
Temiz, A., Nilsson, T., Yıldız, Ü.C., Gezer, E.D., Yıldız, S., 2004. The efficacy of wood preservative treatments in laboratory soil-bed test. In: Proceedings of the IRG 35th Annual Meeting, 6-10 June 2004, Ljubljana, Slovenia, IRG/WP 04-20289.

Temiz, A., Yıldız, Ü.C., Gezer, E.D., Yıldız, S., Dizman, E., 2005. Leaching characteristics of alder wood treated with copper based wood preservatives. In: Proceedings of the IRG 36th Annual Meeting, 24-28 April 2005, Bangalore, India, IRG/WP 05-50225.

Temiz, A., Yildiz, Ü.C., Nilsson, T., 2006. Comparison of copper emission rates from wood treated with different preservatives to the environment. Building and Environment 41, 910-914.

Terziev, N., 2002. Quality of timber impregnated with preservatives of class AB after three years in service. In: Proceedings of the IRG 33th Annual Meeting, 12-17 May 2002, Cardiff, Wales, UK, IRG/WP 02-20241.

Yildiz, S., 2007. Retention and penetration evaluation of some softwood species treated with copper azole. Building and Environment 42, 2305-2310. 